\title{
Erratum to: Earth Observations for Egyptian Coastal Lakes Monitoring and Management
}

Islam Abou El-Magd and Elham Ali

Erratum to:

Chapter "Earth Observations for Egyptian

Coastal Lakes Monitoring and Management" in:

A.M. Negm et al. (eds.), Egyptian Coastal Lakes and

Wetlands: Part II - Climate Change and Biodiversity, Hdb Env Chem, DOI: 10.1007/698_2017_79

Inadvertently, the name of the first mentioned author of the cited reference number 16, Blondeau-Patissier D, was incorrectly mentioned in this chapter. This has now been corrected.

The updated online version of this chapter can be found at DOI 10.1007/698_2017_79 